\title{
METHOD OF BUILDING A MODEL OF OPERATIONAL CHANGES FOR THE MARINE COMBUSTION ENGINE DESCRIBING THE IMPACT OF THE DAMAGES OF THIS ENGINE ON THE CHARACTERISTICS OF ITS OPERATION PROCESS
}

\author{
Bogdan Landowski \\ UTP University of Science and Technology, Poland \\ Michał Pająk \\ University of Technology and Humanities in Radom, Poland \\ Bogdan Żółtowski \\ UTP University of Science and Technology, Poland \\ Łukasz Muślewski \\ UTP University of Science and Technology, Poland
}

\begin{abstract}
This article deals with the modeling of the processes of operating both marine main and auxiliary engines. The paper presents a model of changes in operating conditions of ship's internal combustion engine. The semi-Markov decision process was used to mathematically describe the process model of the engine. The developed model describes the effect of engine damage on the characteristics of its operation.

A change in the input parameters of the model can simulate the influence of internal and external factors on the course of the analyzed process. A simplified calculation example is also presented for illustration purposes.

The presented method together with developed algorithms and IT tools can be used to solve a wide range of problems related to the operation of marine main engines and other marine equipment as well as maritime and port facilities. This concerns primarily the economic, risk management and operational security issues of complex technical systems, as well as the readiness and reliability analysis of technical facilities.
\end{abstract}

Keywords: process of operation, stochastic process, compression ignition engine, condition of object, operating condition

\section{INTRODUCTION}

Although shipping covers the transport of passengers and cargo is carried out between sea ports by ships, it is in the process of transport outside the ships in which other means of transport, equipment and handling systems and other complex technical facilities are used. Many of these means of transport and other technical facilities use compressionignition internal combustion engines in their propulsion systems.
The paper presents the basic assumptions of the method of constructing a model of changes in operating conditions of a technical object describing the influence of its damage on the characteristics of the operation process. The analyzed technical object is a self-ignition internal combustion engine.

The paper deals with selected issues related to modeling, forecasting and controlling the operation process of a certain class of technical objects. Assisting the decision maker in the decision-making process is to evaluate the impact of the decision-making options on the course of the operation. 
The study analyzed the process of change operating states of the internal combustion engine used in transport. As a result of the identification of the process of exploitation of the analyzed object, it was found that this is a nonhomogeneous process.

Due to the purpose of research and the need to model sequences of object states in which the next state and process characteristics depend not only on the previous state but also on other factors for the mathematical modeling of the analyzed process of exploitation, the theory of Markov and semi-Markov processes was used.

The article presents the construction method and example of the model of the process of operation of technical objects, for which the periods of time of analyzed operating states, sequence of consecutive states, revenues and expenses related to staying in states depend not only on the current state but also on other factors.

As a result of the identification of the operation process of means of transport, finite sets of states and operations relevant to the efficiency of their operation were distinguished [14-18, 20].

The model describes, inter alia, the impact of the damage to the propulsion system, in particular its combustion-ignition internal combustion engine, on the course of the operation of such an important means of transport as a seagoing ship.

The operational process model was built on the basis of state space analysis and operational events on the analyzed facilities. The source data sets needed to develop the assumptions of the model and their initial verification were obtained as a result of performing operational research using a passive experiment.

Preliminary operational tests were conducted on a diesel self-combustion engine.

The change of the input parameters of the model can simulate the influence of internal and external factors on the course of the analyzed process. A simplified calculation example is also presented for illustration purposes.

\section{MODELING THE PROCESS OF CHANGES IN ENGINE STATES}

A natural model of the operation of many categories of technical objects is the random process $\mathrm{X}(\mathrm{t})$ with a finite set of states $\mathrm{S}$ and a set of parameters $\mathrm{R}+$ (subset of real numbers $\geq 0)[15,26,27]$. Stochastic homogeneous processes, including homogeneous Markov and semi-Markov processes $[6,8,12-13,18-20,24-27]$ are commonly used for modeling changes in operating states. The use of the homogeneous Markov process to determine the means of decision-making for transport means is illustrated, inter alia, in [19]. This is an important simplification of real processes, which are generally characterized by heterogeneity. In the work on the use of Markov models and semi-Markov models, the assumed assumption of uniformity of modeled processes is generally not verified.
In the study, the states $S_{i}(i=1,2,3,4)$ belonging to the set $S=\left\{s_{1}, s_{2}, s_{3}, s_{4}\right\}$ with the following interpretation were included:

$\mathrm{s}_{1}$ - use status,

$\mathrm{s}_{2}$ - correction state (fitness restoration),

$\mathrm{s}_{3}$ - standby to use state,

$\mathrm{s}_{4}$ - after repair state (so called after repair diagnosis), i.e. the state in which, after the restoration of the fitness of certain motor systems the engine state is examined. The correctness of the execution of correction processes for damaged subsystems is assessed.

It was assumed that the initial model of the operation of the compression ignition engine used in maritime means of transport is a semi-Markov process that is continuous over time and discrete in the states. The operation state codes of the engine are in correlation to the states of the analyzed stochastic process $\left\{\mathrm{X}_{\mathrm{t}}, \mathrm{t} \in \mathrm{T}\right\}, \mathrm{t} \geq 0$. It is assumed that the analyzed process $\left\{X_{t}, t \in T\right\}, t \geq 0$ with a finite set of states $\mathrm{S}=\left\{\mathrm{s}_{1}, \mathrm{~s}_{2}, \mathrm{~s}_{3}, \mathrm{~s}_{4}\right\}$ is a homogeneous process.

From the Markov property, for the analyzed process $\left\{\mathrm{X}_{\mathrm{t}}, \mathrm{t} \in \mathrm{T}\right\}, \mathrm{t} \geq 0$ with a finite set of states $\mathrm{S}$, the probability of transition is defined as follows $[1,2,3,12,13,27]$ :

$P\left\{X\left(\tau_{n+1}\right)=s_{j}, \tau_{n+1}-\tau_{n}<t / X\left(\tau_{n}\right)=s_{i}\right\}=$

$=P\left\{X\left(\tau_{n+1}\right)=s_{j}, \tau_{n+1}-\tau_{n}<t / X\left(\tau_{n}\right)=s_{i}, X\left(\tau_{n-1}\right), \ldots, X\left(\tau_{1}\right), X\left(\tau_{0}\right), \tau_{n}-\tau_{n-1}, \ldots, \tau_{1}-\tau_{0}, \tau_{0}\right\}$ (1)

where:

$\mathrm{S}=\left\{\mathrm{s}_{1}, \mathrm{~s}_{2}, \mathrm{~s}_{3}, \mathrm{~s}_{4}\right\}-$ set of process states $\mathrm{X}(\mathrm{t})$,

$0=\tau_{0}<\tau_{1}<\ldots \tau_{\mathrm{n}-1}<\tau_{\mathrm{n}}$ - random variables representing moments in which process state changes occur $\mathrm{X}(\mathrm{t})$,

$\mathrm{j}, \mathrm{i}-$ numbers of states, which are the values of the process $\mathrm{X}(\mathrm{t}), \mathrm{j}, \mathrm{i}=1,2,3,4$,

$\mathrm{n}$ - the number of the step in which the process state changes $X(t), n \in N$,

$\mathrm{N}$ - set of natural numbers.

The initial distribution of the process $\mathrm{X}(\mathrm{t})$ can be expressed by the relation:

$$
\mathrm{p}_{\mathrm{i}}=\mathrm{P}\left\{\mathrm{X}(0)=\mathrm{s}_{\mathrm{i}}\right\}, \quad \mathrm{s}_{\mathrm{i}} \in \mathrm{S}, \quad \mathrm{i}=1,2,3,4, \sum_{\mathrm{i}=1}^{4} \mathrm{p}_{\mathrm{i}}=1 .
$$

For a homogeneous semi-Markov process, a sequence of random variables $\mathrm{X}\left(\tau_{\mathrm{n}}\right), \quad \mathrm{n} \in \mathrm{N}$ is a homogeneous Markov chain with the probability of passing between states (in n-step) of the form:

$$
p_{i j}=P\left\{X\left(\tau_{n+1}\right)=s_{j} / X\left(\tau_{n}\right)=s_{i}\right\}, \quad i, j=1,2,3,4 .
$$

All Markov chain probability crossovers can be written together in the form of a matrix $\mathrm{P}$ called the probability matrix of the inserted Markov chain:

$$
\mathrm{P}=\left[\mathrm{p}_{\mathrm{ij}}\right]=\left[\begin{array}{llll}
\mathrm{p}_{11} & \mathrm{p}_{12} & \mathrm{p}_{13} & \mathrm{p}_{14} \\
\mathrm{p}_{21} & \mathrm{p}_{22} & \mathrm{p}_{23} & \mathrm{p}_{24} \\
\mathrm{p}_{31} & \mathrm{p}_{32} & \mathrm{p}_{33} & \mathrm{p}_{34} \\
\mathrm{p}_{41} & \mathrm{p}_{42} & \mathrm{p}_{43} & \mathrm{p}_{44}
\end{array}\right], \mathrm{i}, \mathrm{j}=1,2,3,4
$$


$\mathrm{T}_{\mathrm{ij}}$ random variable representing the duration of the $\mathrm{i}$-th state of the process $X(t)$ provided that the next state $j$, is expressed by the dependence:

$$
F_{i j}(t)=P\left\{T_{i j}<t\right\}=P\left\{\tau_{n+1}-\tau_{n}<t / X\left(\tau_{n+1}\right)=s_{j}, X\left(\tau_{n}\right)=s_{i}\right\}
$$

The factors based on the probability limits placed in the Markov chain's semi-Markov process and the values of the expected random variables representing the time intervals of the states are mainly determined.

Among many works $[18,20,26,27]$ as a criterion function $\mathrm{z}$ (the function of the target) a function is assumed whose value is the average profit (loss) that will bring per unit of time used in the system under investigation. This function is expressed by relation:

$$
\mathrm{z}=\frac{\sum_{\mathrm{i}=1}^{4} \mathrm{z}_{\mathrm{i}} \mathrm{p}_{\mathrm{i}}^{*} \mathrm{ET}_{\mathrm{i}}}{\sum_{\mathrm{i}=1}^{4} \mathrm{p}_{\mathrm{i}}^{*} \mathrm{ET}_{\mathrm{i}}},
$$

where:

$\mathrm{z}_{\mathrm{i}}$ - profit per time unit associated with staying in a state $s_{\mathrm{i}}$, $\mathrm{p}_{\mathrm{i}}^{*}$ - limit probability of an inserted Markov chain,

$\mathrm{ET}_{\mathrm{i}}$ - expected value of the random variable representing the residence time of the object in the process state $s_{i}$.

In many works, including [6-8, 12-13, 18, 20, 24-27] general properties of semi-Markov processes are described and their applicability to the analysis of processes of exploitation of technical objects is justified.

The use of semi-Markov processes to model the change process in operating and/or technical conditions of an internal combustion engines, including marine diesel engines, has been reported in $[7,10]$.

In many cases, changes in the technical condition or operating facility, including the internal combustion engine, are made in certain operations, decisions or occurrences of certain operational events affecting sequences of successive states, duration or economic characteristics of the process. In this case, decision-making stochastic processes may be useful for modeling changes in the state of an internal combustion engine.

Many researchers have taken up the problem of using both Markov chains [5], Markov processes [19, 22-23] and semi-Markov $[1-3,10,11,14,16,17,20,28]$ for mathematical modeling real processes, including the modeling of processes of changes in operating conditions of technical objects. In the literature of the subject one will find many articles concerning both theoretical description and examples of practical applications of this type of models. The use of decisionmaking semi-Markov processes for modeling changes in operating states and/or technical internal combustion engines, including main engines used for propulsion of ships, is presented, inter alia, in $[9,10,24]$.

\section{SELECTED FEATURES OF THE CHANGE PROCESS OF AN INTERNAL COMBUSTION ENGINE OPERATIONAL STATUS}

As a formal description of the process of changing the technical and operational conditions of complex technical objects such as compression-ignition internal combustion engines and the model of this process in the form of a stochastic process, the values of which are the operational and operational statuses of practical importance, $[18,20$, $26,27]$, only selected features of the analyzed process are presented in this paper.

As a result of the identification of the operation process of the analyzed combustion-ignition internal combustion engines, finite sets of states and operational events are significant for their efficient operation.

Possible transition between states have been determined. Operational states are characterized by distributions of random variables indicating their duration, expenditures and revenues per unit of time associated with staying in states. Entry into the state can be related to revenue or effort.

In the computational example, the selected subsets of these states and events were analyzed.

As a result of the identification of the analyzed process of exploitation and carried out operational research, the following regularities were observed $[14,16,17]$ :

- after the repair of specific engine systems, it is necessary to perform a status check, i.e. the status of the engine status check is only possible after repairs of the identified engine failures;

- if, after the execution of the engine condition check, the continuation of work is prevented by the object being repaired, the workpiece is subject to repairs at the workstation where the condition of the work has been carried out;

- the cost per unit of time associated with the performance of the engine repair is related to the type of damaged subsystem;

- repair time depends on the type of the damaged engine subsystem;

- maintenance time depends on the outcome of the status check, i.e. whether the engine will be allowed to perform tasks or will be repaired again;

- the cost per unit of time associated with the execution of a repaired object is related to the result of its state control.

Based on preliminary operational research $[14,18,20,28]$ it can be concluded that an example of a means of transport that damages sequences of successive states of operation and their characteristics is the drive system. In the analyzed object with relatively high frequency there is damage to the engine power supply system requiring adjustment of the injection pump. The correction procedure used for this system provides for the necessity of carrying out a maintenance diagnosis.

For the purposes of the simplified computational example (Section 6), the combustion engine subsystem (damage to its components) was divided into three subsets denoted by $\mathrm{U}_{\mathrm{u}}$, $\mathrm{u}=1,2$, 3 , i.e. $[14,16,17]$ : 
- subsystems (damage to their components) characterized by low labor-intensive repairs, which average repair time is relatively short; Restoring fitness does not require the engine to be transferred to specialized technical facilities; A subset of these subsystems is marked with code $\mathrm{U}_{1}$ :

- subsystems which, after failure and recovery, require remediation processes; A subset of these subsystems is marked with code $\mathrm{U}_{2}$,

- subsystems with high repair workloads which average repair time is relatively long (multiple subsystems classified under subset $U_{1}$ ); A subset of these subsystems is designated $\mathrm{U}_{3}$.

Selected characteristics of operating states and semiMarkov model of the change process of operating states of the means of transport, in which the impact of damage on the course of the exploitation process is analyzed is presented in the papers $[18,27]$.

\section{MATHEMATICAL MODEL OF ENGINE OPERATION PROCESS}

It was assumed that the engine can, at a given time $t, t>0$, be present in only one of the distinguished states, constituting a finite set of operating states of the object.

The operating state change process model of the engine is a stochastic process $\left\{\mathrm{X}_{\mathrm{t}}, \mathrm{t} \in \mathrm{T}\right\} \mathrm{t} \geq 0$ for a finite set of states $\mathrm{S}=\left\{\mathrm{s}_{1}, \mathrm{~s}_{2}, \mathrm{~s}_{3}, \mathrm{~s}_{4}\right\}$.

The probability of change of state in one step of the process $\left\{X_{t}, t \in T\right\}$ from the state $s_{i}, s_{i} \in S$ to the state $s_{j}, s_{j} \in S_{4}$ at the occurrence of the condition $\mathrm{a}, \mathrm{a} \in \mathrm{A}$ is marked $\mathrm{p}_{\mathrm{ij}}^{\mathrm{a}}, \sum_{\mathrm{j}=1}^{4} \mathrm{p}_{\mathrm{i}}^{\mathrm{a}}=1$, $\mathrm{p}_{\mathrm{ij}}^{\mathrm{a}} \geq 0$ for $\mathrm{i}, \mathrm{j}=1,2,34$ and $\mathrm{a} \in \mathrm{A}$.

Continued process states $\left\{\mathrm{X}_{\mathrm{t}}, \mathrm{t} \in \mathrm{T}\right\}$ is heterogeneous Markov chain.

If all random variables signifying the duration of process states $\left\{\mathrm{X}_{\mathrm{t}}, \mathrm{t} \in \mathrm{T}\right\}$ have exponential distributions then such a defined stochastic process is a special case of the nonstationary decision-making process of Markov process [23, 26]. If the random variables signifying the duration of process states $\left\{\mathrm{X}_{\mathrm{t}}, \mathrm{t} \in \mathrm{T}\right\}$ can have any distribution, then the analyzed stochastic process is a special case of the non-stationary decision of the semi-Markov process [1-3].

Semi-Markov decision processes are used, inter alia, for modeling the process of changes in operating states and technical conditions of complex technical systems. These processes according to [10] are a convenient mathematical tool for analyzing decision problems related to the operation of marine combustion engines.

Due to the character of the paper, only selected assumptions of the simplified model of the engine operation process are presented.

The main assumptions used to describe the stochastic process $\left\{\mathrm{X}_{\mathrm{t}}, \mathrm{D}_{\mathrm{t}}, \mathrm{t} \in \mathrm{T}\right\}, \mathrm{t} \geq 0$ are the mathematical model of the analyzed process of operation.

It has been assumed that the process of changing the operating conditions of the engine is described by the stochastic process:

$$
\left\{\mathrm{X}_{\mathrm{t}}, \mathrm{t} \in \mathrm{T}\right\}, \mathrm{t} \geq 0
$$

with finite state space:

$$
\mathrm{S}=\left\{\mathrm{s}_{1}, \mathrm{~s}_{2}, \mathrm{~s}_{3}, \mathrm{~s}_{4}\right\},
$$

where:

$\mathrm{T}$ - subset of real numbers.

In this paper we assume that the states of the stochastic process under consideration correspond to the states of engine operation.

$\mathrm{a}_{\mathrm{ik}},(\mathrm{i}=1,2,3,4, \mathrm{k} \in \mathrm{N})$ denotes the action (decision) $\mathrm{k}$ taken at $s_{i}$. Each is made up of $s_{i}, s_{i} \in S$ corresponding to a finite set of actions $\mathrm{A}_{\mathrm{i}}$ (decisions).

It was assumed that elements of the set $\mathrm{A}_{\mathrm{i}}, \mathrm{i}=1,2,3,4$ are the elements $\mathrm{a}_{\mathrm{ik}},(\mathrm{i}=1,2,3,4, \mathrm{k} \in \mathrm{N})$, i.e.:

$$
\mathrm{A}_{\mathrm{i}}=\left\{\mathrm{a}_{\mathrm{i}, 1}, \mathrm{a}_{\mathrm{i}, 2}, \ldots, \mathrm{a}_{\mathrm{i}, \mathrm{i}}\right\},
$$

where:

$\overline{\overline{\mathrm{i}}}$ - means power of the set $\mathrm{A}_{\mathrm{i}}$.

The set of all subsets of actions is denoted by A, i.e.:

$$
A=\bigcup_{i=1}^{4} A_{i}
$$

In the general case, $\mathrm{a}_{\mathrm{ik}}$ action taken at process input $\left\{\mathrm{X}_{\mathrm{t}}, \mathrm{t} \in \mathrm{T}\right\}$ to $\mathrm{s}_{\mathrm{i}}$ can affect both the process state and the state of $s_{i}$, the type and the distribution parameters of the random variable representing the dwell time, costs, or gains in this state, etc.).

Actions may represent the way in which operations, tasks, events, decisions are made, etc., which can be attributed to the state of the modeled process [14-18, 27-29]. In the actual operating system there may be different ways of servicing, repairs, inspections, ranges of activities performed or usage of an object, etc. Adoption of a given action can affect: costs incurred, revenues, frequencies and types of damage of an object, sequences of states, etc. [27-29].

For the analyzed object, the elements of $\mathrm{a}_{\mathrm{ik}}$ subsets $A_{i}$ were interpreted in step 6 of the work. Considered in the computational example (point 6), set A has the form $A=\left\{a_{1,1}, a_{2,1}, a_{2,2}, a_{2,3}, a_{3,1}, a_{4,1}, a_{4,2}\right\}$.

Stochastic process:

$$
\left\{\mathrm{D}_{\mathrm{t}}, \mathrm{t} \in \mathrm{T}\right\}, \mathrm{t} \geq 0 \text {, }
$$

with a finite set of actions $\mathrm{A}$ describes how $\mathrm{a} \in \mathrm{A}$ is chosen.

The change of the state of the process $\left\{D_{t}, t \in T\right\}$ occurs at $t$ times of process states $\left\{X_{t}, t \in T\right\}$. At moments $t_{n}, n \in N$ of process states changes $\left\{X_{t}, t \in T\right\}$, the action $a \in A$ is selected. 
If at the moment $t_{n}$ the state of the process $\left\{X_{t}, t \in T\right\}, s_{i}$ is the state of being, then $\mathrm{a} \in \mathrm{A}_{\mathrm{i}}$.

Process $\left\{\mathrm{X}_{\mathrm{t}}, \mathrm{D}_{\mathrm{t}}\right\}, \mathrm{t} \geq 0$ with finite sets of states $\mathrm{S}$ and finite set of actions $\mathrm{A}$, is called a decision-making stochastic process. As a result of this process from the initial time $t_{0}$ to the moment $t_{n}$, a sequence of states and decisions is obtained, which is called the process history until $t_{n}$ :

$$
h_{t_{n}}=\left\{s_{i_{0}}, a_{t_{0}}, s_{i_{1}}, a_{t_{1}}, \ldots, s_{i_{n}}, a_{t_{n}}\right)
$$

where:

$\mathrm{t}_{\mathrm{m}}$ - moments in which process conditions change $\left\{\mathrm{X}_{\mathrm{t}}, \mathrm{D}_{\mathrm{t}}\right\}, \mathrm{m}=0,1, \ldots, \mathrm{n}$,

$\mathrm{s}_{\mathrm{it}_{\mathrm{m}}}-$ process state $\left\{\mathrm{X}_{\mathrm{t}}, \mathrm{t} \in \mathrm{T}\right\}$ at moment $\mathrm{t}_{\mathrm{m}}$, e.g. $\mathrm{X}\left(\mathrm{t}_{\mathrm{m}}\right)=\mathrm{s}_{\mathrm{i}}$, $s_{i} \in S$,

$a_{t_{m}}$ - the process state $\left\{D_{t}, t \in T\right\}$ at moment $t_{m}$, i.e. $D\left(t_{m}\right)=a$, $a \in A$,

$\mathrm{m}-$ the number of step in which the process $\left\{X_{t}, D_{t}\right\}$ states change.

For the mathematical modeling of the described process of changes in the state of a technical object, Markov decisionmaking processes $[19,22-23]$ or semi-Markov [1-3, 9-11, 14, $16-17,19-20,22-23,28]$ can be used. Based on the analysis of the results of the conducted studies on the duration of operating states, the hypothesis about the compatibility of time distributions with the exponential distribution was rejected, it was further assumed that the analyzed decisionmaking process of stochastic:

$$
\left\{\mathrm{X}_{\mathrm{t}_{\mathrm{n}}}, \mathrm{D}_{\mathrm{t}_{\mathrm{n}}}\right\}_{\mathrm{n}=1}^{\infty},
$$

is a semi-Markov decision-making process. Accepting such an assumption implies, inter alia, that random variables describing the duration of process states $\left\{\mathrm{X}_{\mathrm{t}}, \mathrm{t} \in \mathrm{T}\right\}$ can have any distribution. The set of possible realizations of the analyzed decision process is $\mathrm{W}=\{\mathrm{S} \times \mathrm{A}\}^{\infty}$ set. It has also been assumed that the probability of action $\mathrm{a}_{\mathrm{t}_{\mathrm{n}}} \in \mathrm{A}$ selection depends only on the state $s_{i_{n-1}} \in S$, and does not depend on the history $h_{t_{n-1}}$ of the process.

In this case, the process state sequence $\left\{\mathrm{X}_{\mathrm{t}}, \mathrm{t} \in \mathrm{T}\right\}$ is a nonhomogeneous Markov chain [3-5].

In order to define the analyzed stochastic decision process $\left\{X_{t}, D_{t}\right\}, t \geq 0$ one should also define:

- the way of choosing a process action $\left\{\mathrm{D}_{\mathrm{t}}, \mathrm{t} \in \mathrm{T}\right\}$,

- initial distribution of the process $\left\{\mathrm{X}_{\mathrm{t}}, \mathrm{t} \in \mathrm{T}\right\}$,

- conditional probabilities of process state changes $\left\{X_{t}, t \in T\right\}$,

- random variables representing the duration of process states $\left\{\mathrm{X}_{\mathrm{t}}, \mathrm{t} \in \mathrm{T}\right\}$.

In a very simplified way, the rule that determines how to choose when entering the state of action is called a strategy. The method of selecting action at the input of the process state may be random or determined.
By:

$$
\mathrm{p}=\left[\mathrm{p}_{1}, \mathrm{p}_{2}, \mathrm{p}_{3}, \mathrm{p}_{4}\right], \sum_{\mathrm{i}=1}^{4} \mathrm{p}_{\mathrm{i}}=1, \mathrm{p}_{\mathrm{i}} \geq 0
$$

the initial distribution of the process $\left\{\mathrm{X}_{\mathrm{t}}, \mathrm{t} \in \mathrm{T}\right\}$ is determined.

Given the value $p_{i}$ of elements of the initial distribution vector $\mathrm{p}$, the probability of finding the process $\{\mathrm{Xt}, \mathrm{t} \hat{\mathrm{I} T}\}$ at time $t=0$ in the state $s_{i}$.

The probability of change of state in one step of the process $\left\{X_{t}, t \in T\right\}$ from state $s_{i}, s_{i} \in S$ to $s_{j}, s_{j} \in S$ when taken at input $s_{i}$ and $\mathrm{a} \in \mathrm{A}_{\mathrm{i}}$ are determined as $\mathrm{p}_{\mathrm{ij}}^{\mathrm{a}}$.

The condition is fulfilled:

$$
\sum_{j=1}^{4} p_{i j}^{a}=1, p_{i j}^{a} \geq 0, \text { for all } \mathrm{i}, j=1,2,3,4 \text { and } a \in A_{i}
$$

For each state $s_{i}, s_{i} \in S$ and action $a, a \in A_{i}$, a stochastic matrix $\mathrm{P}^{(\mathrm{i}, \mathrm{a})}$ can be assigned to determine the conditional probability of the transition $\mathrm{p}_{\mathrm{ij}}^{\mathrm{a}}$. The array of matrices attributed to the $s_{i}, s_{i} \in S$ state is the power equal $\bar{i}$ (the power of the set $A_{i}$ ).

The matrix $\mathrm{P}^{(\mathrm{i}, \mathrm{a})}$ is a matrix of stochastic lines that determines the probability of transition from state $s_{\mathrm{i}}$ (index and state $\mathrm{s}_{\mathrm{i}}$ corresponds to the row of the matrix $\mathrm{P}^{(\mathrm{i}, \mathrm{a})}$ ) to all remaining states. The element $\mathrm{p}_{\mathrm{ij}}^{\mathrm{a}}$ at the intersection of the line with the number $i$ and the column $j$ with the matrix $\mathrm{P}^{(\mathrm{i}, \mathrm{a})}$ is the probability of transition from state $s_{i}, s_{i} \in S$ to $s_{j}, s_{j} \in S$ if when entering state $s_{i}, s_{i} \in S, a \in A_{i}$ is applied.

The random variable signifying the duration of the process $\{\mathrm{Xt}, \mathrm{tÎT}\}$ state $s_{\mathrm{i}} \in \mathrm{S}$, when the next state is the state $\mathrm{s}_{\mathrm{j}} \in \mathrm{S}$, and when entering the $s_{i} \in S$ state, with undertaken action $a \in A_{i}$ determined by the distribution $\mathrm{F}_{\mathrm{ij}}^{\mathrm{a}}(\mathrm{t})$, is determined by the symbol $\mathrm{T}_{\mathrm{ij}}^{\mathrm{a}}$.

For the sake of simplicity in further consideration it was assumed that:

$$
\mathrm{F}_{\mathrm{ij}}^{\mathrm{a}}(\mathrm{t})=\mathrm{F}_{\mathrm{i}}^{\mathrm{a}}(\mathrm{t})=\mathrm{F}_{\mathrm{ia}}(\mathrm{t}), \mathrm{i}, \mathrm{j}=1,2,3,4, \mathrm{a} \in \mathrm{A}_{\mathrm{i}} \text {. }
$$

This means that the duration of the process $\{\mathrm{Xt}, \mathrm{t} \in \mathrm{T}\}$ state does not depend on the next state in which the process will be located. The function $\mathrm{F}_{\mathrm{ia}}(\mathrm{t})$ is the distribution of the time distribution of the states of $s_{i}, s_{i} \in S$, provided that upon entry into this state the action a is taken.

The random variable signifying the duration of the $s_{i}, s_{i} \in S$ state of the distribution determined by the distribution $\mathrm{F}_{\mathrm{ia}}(\mathrm{t})$ is denoted by the symbol $\mathrm{T}_{\mathrm{ia}}$.

In order to assess the economic aspects associated with the implementation of the modeled operation process, it is necessary to additionally determine the relevant economic category values associated with the way in which the process states enter and stay in the process.

In addition, it was assumed that the model of changes in operating states of a homogeneous $n$ set from the 
point of view of the objective of testing technical objects are independent processes $\left\{\mathrm{X}_{\mathrm{t}}, \mathrm{t} \in \mathrm{T}\right\}$. The random vector $\mathrm{X}(\mathrm{t})=\left[\mathrm{X}_{1}(\mathrm{t}), \mathrm{X}_{2}(\mathrm{t}), \ldots, \mathrm{X}_{\mathrm{n}}(\mathrm{t})\right]$ describes the process of changing the operation states of a set of objects [15].

In practical applications, it is necessary to verify that there are no grounds for rejecting assumptions resulting from the applied mathematical apparatus.

A computer program has been developed to simulate the realization of a particular stochastic process. In the course of the simulation, the values of selected sets of indicators are determined which allow analysis of the modeled process of changing the engine states.

\section{SIMULATION OF THE OPERATIONAL PROCESS IMPLEMENTATION}

Analytical determination of the characteristics of the process of operation, which model is described decision stochastic process is a complex problem. In literature, the most commonly studied models are of small numbers of states and actions, and at the same time, there are limited opportunities for transition between states. Analysis of the operating conditions of complex technical facilities, including means of transport and the ongoing exploitation process often points to the need to consider more states considered significant and actions taken in states.

The authors of papers $[18,20,27]$ consider more numerous states of space containing up to a dozen states of operation and analyze the characteristics of the process of operation of a technical object as a result of simulation of the process of stochastic process as a model of the process of changing the state of an object.

It seems that the numerical simulation of the process of changes in operating and technical states and the determination of selected values of characteristics on the basis thereof may be helpful in analyzing the process of operation of an object [14-18, 20-21, 27-29].

For the described assumptions, the simulation of the engine operation process consists of simulating the implementation of the described stochastic decision-making process, which is a model of the process of changing the engine operating states.

Numerical simulation algorithms of the decision-making process of the stochastic process have been developed. The data necessary for the simulation are the data necessary to determine the described process $\left\{X_{t}, D_{t}\right\}, t \geq 0$.

A computer program has been developed to simulate the realization of a particular stochastic process. During the implementation of the simulation, the values of the selected indicators allowing to analyze the modeled process of changing the state of objects are determined.

The algorithm and computer program developed enable the decision-making process of the semi-Markov process to be performed for both the number of states and actions that can be applied at the entry of particular states, and types of timestamps that are implemented in the program. The above values are given as input parameters of the simulation program. The collection of all input data needed to execute the simulation experiments is prepared in the form of Excel spreadsheets.

With regard to decision strategies, the program enables the implementation of stationary strategies determined by the distribution of the probability of choosing a particular action (decision) for each state. A particular case of stationary strategy is a deterministic strategy for which a state is always used for a particular state with probability equal to one and the same action.

Using the developed program, it is possible to simulate the execution of stationary processes in the sense that one matrix of probabilities of transitions between process states $\left\{\mathrm{X}_{\mathrm{t}}, \mathrm{t} \in \mathrm{T}\right\}$ and non-stationary ones for the duration of the whole simulation $\left(\mathrm{p}_{\mathrm{ij}}^{\mathrm{a}}=\mathrm{p}_{\mathrm{ij}}\right)$ - and non-stationary states, i.e. for each state and action (decision), a different probability matrix is used.

The characteristics of the developed simulation program and examples of numerical simulations are presented in [15-17, 20, 28].

As a result of the numerical simulation of the process of changing the operating conditions of the engine, the following are measured for the time interval: inter alia, the number of faults of the analyzed engine subsystems, the total repair time of the damaged subsystems, the readiness of the engine and the time between faults.

\section{CALCULATION EXAMPLE}

For illustration purposes, the influence of the type of damaged object subsystem on the likelihood of transition between analyzed states and time intervals and the costs of staying in states is modeled.

Due to the nature of the study, the presented calculation example is characterized by considerable simplification. The selected features of the process of alteration of operating conditions of the internal combustion engine (section 3) have been modeled.

In the analyzed example, process states $\left\{\mathrm{X}_{\mathrm{t}}, \mathrm{t} \in \mathrm{T}\right\}$ correspond to the highlighted operating states $S_{i}, i=1,2,3$, 4 of the engine.

The states $s_{1}$ and $s_{3}$ of the process $\left\{\mathrm{X}_{\mathrm{t}}, \mathrm{t} \in \mathrm{T}\right\}$ are so-called non-decisive states. This means, that the subsets of actions $\mathrm{A}_{1}$ and $\mathrm{A}_{3}$ are one-element. In these states, actions are only formal (consistency of writing) and have no influence on the course of the analyzed process $\left\{\mathrm{X}_{\mathrm{t}}, \mathrm{D}_{\mathrm{t}}\right\}, \mathrm{t} \geq 0$.

In state $s_{2}$, the actions $a \in A_{2}$ of the process $\left\{D_{t}, t \in T\right\}$ correspond to the code of the damaged subsystems of the engine and map its faults (point 3). The set $A_{2}$ contains the following elements $A_{2}=\left\{a_{2,1}, a_{2,2}, a_{2,3}\right\}$. Actions $a_{2,1}, a_{2,2}, a_{2,3}$ denote damage to the selected motor subsystems $U_{1}, U_{2}$, and $U_{3}$, respectively. Interpreting the input at time t to process $\left\{\mathrm{X}_{\mathrm{t}}, \mathrm{t} \in \mathrm{T}\right\}$ state $\mathrm{s}_{2}$ and occurrence of action $\mathrm{a}_{2,3}$ of process $\left\{\mathrm{D}_{\mathrm{t}}, \mathrm{t} \in \mathrm{T}\right\}$ is as follows: engine has been damaged and serviced and damaged subsystem is marked with code $\mathrm{U}_{3}$. Interpretation of actions $\mathrm{a}_{2,1}, \mathrm{a}_{2,2}$ possible to occur in this state is analogous and concerns respectively the subsystems $\mathrm{U}_{1}$ and $\mathrm{U}_{2}$. 
In state $\mathrm{s}_{4}$, the actions $\mathrm{a} \in \mathrm{A}_{4}$ of the process $\left\{\mathrm{D}_{\mathrm{t}}, \mathrm{t} \in \mathrm{T}\right\}$ correspond to the engine status control codes. The set $\mathrm{A}_{4}$ contains the following elements $\mathrm{A}_{4}=\left\{\mathrm{a}_{4,1}, \mathrm{a}_{4,2}\right\}$. By $\mathrm{a}_{4,1}$ and $\mathrm{a}_{4,2}$, respectively, the positive status of the engine status check and the need for re-handling are indicated.

The rule of action a selection in the state of $s_{i}, i=1,2,3,4$ determines the distribution of the probability of occurrence of the analyzed actions. It has been assumed that $\mathrm{q}_{\mathrm{ik}}$, $\mathrm{i}=1,2,3,4, \mathrm{k} \in \mathrm{N}$ denotes the probability of $\mathrm{a}_{\mathrm{ik}}$ action at the $\mathrm{s}_{\mathrm{i}}$ input.

By

$\mathrm{q}_{\mathrm{i}}=\left[\mathrm{q}_{\mathrm{i} 1}, \mathrm{q}_{\mathrm{i} 2}, \ldots, \mathrm{q}_{\mathrm{ik}}\right], \mathrm{q}_{\mathrm{ik}} \geq 0, \mathrm{i}=1,2,3,4, \mathrm{k} \in \mathrm{N}$,

the vector of the distribution of the occurrence of the action $i$ is determined. The vector elements $q_{i}$ satisfy the condition:

$$
\sum_{i=1,2,3,4 ; k \in N} q_{i k}=1
$$

In the example under consideration, the elements of this vector for $i=2$ denote the probability of damage to the engine subsystem denoted by code $\mathrm{k}$.

In order to illustrate the considerations, simulation experiments were performed for the scenario under consideration.

In the simulation experiments it was assumed that the random variables $T_{i a}$ for $i=1,2,3,4, a \in A$ have gamma distributions with different parameters, and the process state is related to obtaining revenue (state $s_{1}$ ) and the expenditure of the system in which objects are operated. The values determining the conditional probabilities of the transition $\mathrm{p}_{\mathrm{ij}}^{\mathrm{a}}$ of the stochastic matrix $\mathrm{P}^{(\mathrm{i}, \mathrm{a})} \mathrm{i}, \mathrm{j}=1,2,3,4$, $\mathrm{a} \in \mathrm{A}$ were estimated on the basis of the results of preliminary operational tests.

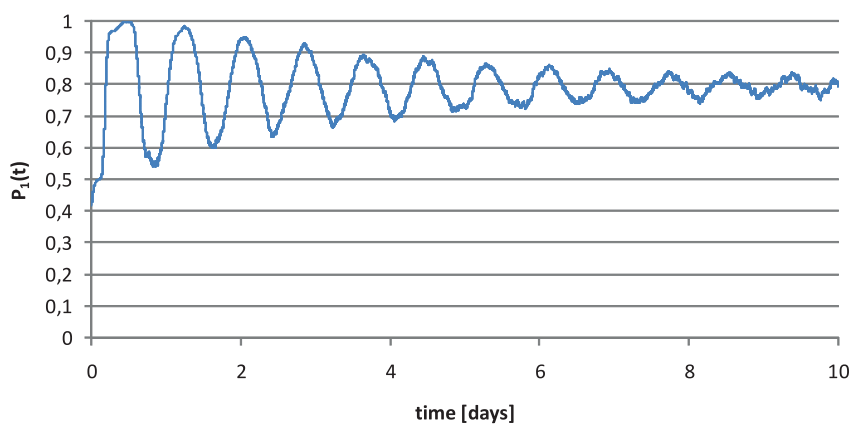

Fig. 1. Probability of $P_{1}(t)$ the analyzed engine occurring in use state

The probability values of $\mathrm{q}_{\mathrm{ik}}, \mathrm{i}=2, \mathrm{k}=1,2,3$ of the $\mathrm{a}_{\mathrm{ik}}$ actions were determined on the basis of the results of the investigations of damage of the analyzed internal combustion engines.
The remaining parameter values used for the simulation experiments were estimated on the basis of the preliminary results.

It should be assumed that the values used for the distribution of random variables $\mathrm{T}_{\mathrm{ia}}, \mathrm{i}=1,2,3,4, \mathrm{a} \in \mathrm{A}$ are hypothetical. Values of parameters were estimated on the basis of a lowvolume dataset.

Figures 1 to 4 show the course of changes in probability values $\mathrm{P}_{\mathrm{i}}(\mathrm{t})$ of the analyzed process $\left\{\mathrm{X}_{\mathrm{t}}, \mathrm{D}_{\mathrm{t}}\right\}, \mathrm{t} \geq 0$ in the states of $\mathrm{S}_{\mathrm{i}}, \mathrm{i}=1,2,3,4$.

Presentation of the full set of input data used to perform simulation experiments and numerical simulation results goes beyond the scope of the study.

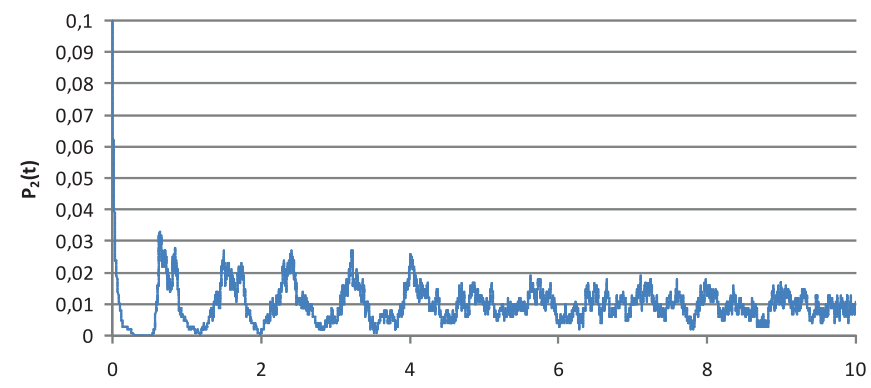

Fig. 2. Probability of $P_{2}(t)$ the analyzed engine occurring in the state of maintenance control

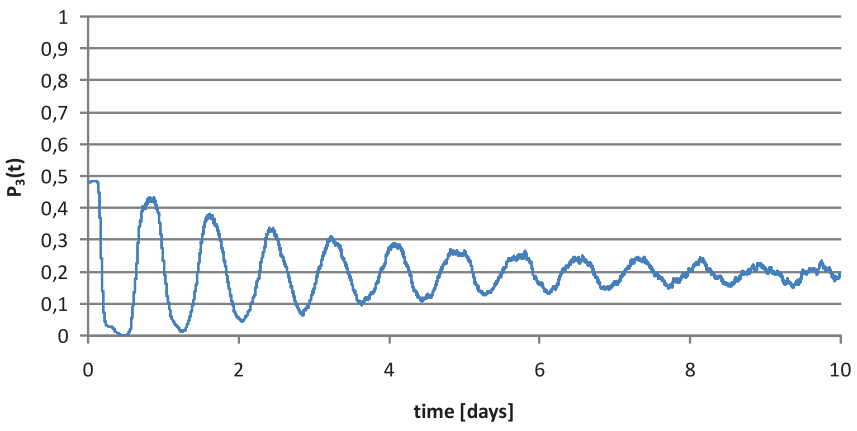

Fig. 3. Probability of $P_{3}(t)$ the analyzed engine occurring in standby state

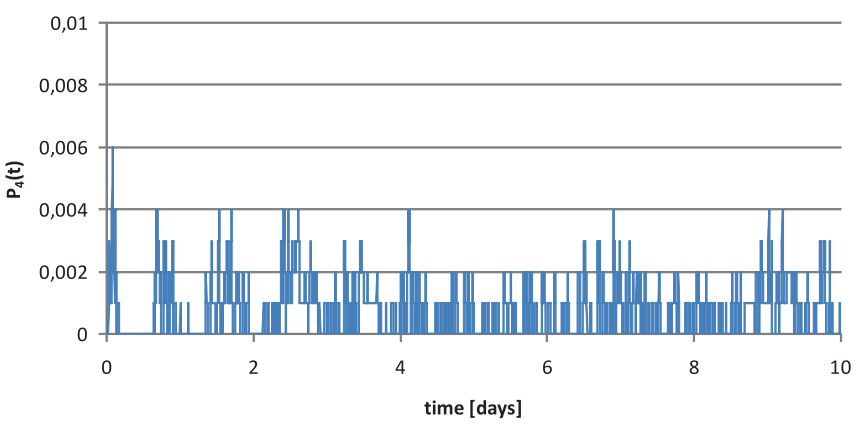

Fig. 4. Probability of $P_{4}(t)$ the analyzed engine occurring in the state of reparation 


\section{SUMMARY}

The purpose of this paper, among others, was to describe the possibilities of using semi-Markov decision-making theories for modeling the operation of internal combustion engines for main propulsion of ships, including propulsion systems of such means and other equipment that have a significant impact on the reliability and safety of maritime transport.

The method proposed in the article can be used to build similar models of other marine propulsion systems, as well as any means of maritime transport.

In the operation phase, such models can be used to predict changes in the characteristics of the modeled process description, as well as to estimate the value of the reliability and safety indicators and other operating indicators.

Numerical simulation of the semi-Markov decisionmaking process as a model of the process of change of the state of the analyzed combustion engine used in marine means of transport enables to determine the characteristics of the process which cannot be determined by the analytical method.

It seems possible and appropriate to use this type of tool to analyze multi-tasking processes and assist decision-makers in the decision-making process regarding the operation of internal combustion engines, means of transport and other complex technical objects, e.g. by predicting the behavior of an object after a change of control forces.

The set of possible indicators includes subsets of indicators for: readiness, repair time, performance, costs, and more.

The presentation of the full set of input data needed to simulate the analyzed stochastic process and how the model parameter values that are estimated based on the results of actual operational data is beyond the scope of this study. Due to the nature of the work and the extensive range of results generated, only selected results of simulation experiments are presented. The simulation results presented are illustrative.

The model presented in the paper has been designed in such a way that it can be used in a wide range of problems related to the operation of technical objects, including both the description of the effect of damage on the characteristics of the operation of the main engine and marine auxiliary engines.

The presented method together with developed algorithms and IT tools can be used to solve a wide range of problems related to the operation of marine main engines and other marine equipment as well as maritime and port facilities. This concerns primarily the economic, risk management and operational security issues of complex technical systems, as well as the readiness and reliability analysis of technical facilities.

\section{BIBLIOGRAPHY}

1. Baykal-Gürsoy M.: Semi-Markov Decision Processes. Wiley Encyclopedia of Operations Research and Management Sciences, 2010.

2. Baykal-Gürsoy M., Gürsoy K.: Semi-Markov Decision Processes: Nonstandard Criteria, Probability in the Engineering and Informational Sciences, Vol. 21:4, pp. 635-657.

3. Bernaciak K.: Zastosowanie decyzyjnych procesów semimarkowskich do optymalizacji eksploatacji pewnego urzadzenia. Zagadnienia Eksploatacji Maszyn, Zeszyt 3 (75), 1988.

4. Buslenko, N., Kałasznikow, W., Kowalenko, I.: Theory of complex systems, PWN, Warsaw 1979.

5. Chrzan P.: Łańcuchy decyzyjne Markowa i ich zastosowania w ekonomii. Akademia ekonomiczna, Katowice 1990.

6. Girtler J.: Application of theory of semi-Markov processes to determining distribution of probabilistic process of marine accidents resulting from collision of ships. Polish Maritime Research 2014 nr 1, pp. 9-13.

7. Girtler J.: Stochastyczny model procesu eksploatacji okrętowego silnika spalinowego. Zagadnienia Eksploatacji Maszyn 1989 nr 2, s. 79-88.

8. Girtler J.: Physical aspect of application and usefulness of semi-Markovian processes for modeling the processes occurring in operational phase of technical objects. Polish Maritime Research 2004, nr 3(41), vol. 11, pp. 25-30.

9. Girtler J.: Possibility of estimating the reliability of diesel engines by applying the theory of semi-Markov processes and making operational decisions by considering reliability of diagnosis on technical state of this sort of combustion engines. Combustion Engines. 2015, vol. 163(4), pp. 57-66.

10. Girtler, J.: Usefulness of semi-Markov processes as models of the operation processes for marine main engines and other machines of ship power plants. Journal of Polish CIMAC, 9(2), Gdańsk 2014, pp. 57-67.

11. Grabski F.: Analiza ryzyka w decyzyjnych semi-markowskich modelach procesu eksploatacji. XXXVIII Zimowa Szkoła Niezawodności, Szczyrk, 2010.

12. Grabski F.: Semi-markowskie modele niezawodności i eksploatacji. PAN IBS, seria: Badania Systemowe, t. 30, Warszawa 2002. 
13. Grabski F.: Teoria semi-markowskich procesów eksploatacji obiektów technicznych. Zeszyty Naukowe AMW, nr 75 A, Gdynia 1982.

14. Kostek R., Landowski B., Muślewski Ł.: Simulation of rolling bearing vibration in diagnostics. Journal of Vibroengineering 2015, volume 17, issue 8, pp. 42684278, ISSN 1392-8716.

15. Landowski B.: An example of a technical object operation process model describing influence of engine damages on the operation process course. Journal of POLISH CIMAC Vol. 9, No. 3, Gdańsk 2014.

16. Landowski B.: Example of applying Markov decision process to model vehicle maintenance process. Journal of KONES Powertrain and Transport, Vol. 20, No. 4, 2013, European Science Society of Powertrain and Transport Publication, Warsaw 2013.

17. Landowski B.: Example of Markov decision process use for modelling of operation and maintenance process. Interdisciplinary Integration of Science in Technology, Education and Economy. Monograph: edited by Shalapko J. and Żółtowski B., Khmelnytsky - Jaremche 2013, ISBN 978-617-70-94-07-3.

18. Landowski B.: Method of determination values of the chosen decision variables to control rationally the operation and maintenance process in the transport system. Doctoral thesis, Academy of Technology and Agriculture, Bydgoszcz 1999.

19. Landowski B, Perczyński D., Kolber P., Muślewski Ł.: An example of Markov model of technical objects maintenance process. Engineering Mechanics 2016, 22nd International Conference, may 9 - 12, 2016, Svratka, Czech Republic, Book of full texts, Institute of Thermomechanics Academy of Sciences of the Czech Republic, 2016, pp. 346-349, ISBN 978-80-87012-59-8, ISSN 1805-8248.

20. Landowski B., Woropay M., Neubauer A.: Sterowanie niezawodnościa w systemach transportowych. Biblioteka Problemów Eksploatacji, Wydawnictwo Instytutu Eksploatacji Maszyn, Bydgoszcz - Radom 2004.

21. Łukasiewicz M., Kałaczyński T., Musiał J, Shalapko J.: Diagnostics of buggy vehicle transmission gearbox technical state based on modal vibrations. Journal of Vibroengineering 2014, volume 16, issue 6,pp. 3137-3145, ISSN 1392-8716.

22. Puterman M. L.: Markov decision processes. John Wiley, New York, 1994.

23. Puterman M. L.: Markov decision processes: discrete stochastic dynamic programming. John Wiley \& Sons 2014.
24. Rudnicki J.: Application isssues of the semi-markov reliability model. Polish Maritime Research 2015, nr 1(85), vol. 22, pp. 55-64.

25. Rudnicki J.: The time of the first transition of the semiMarkov process in the evaluation of diesel engine operation. Silniki Spalinowe 2011, tom R. 50, nr 3, pp. 89-98.

26. Woropay M., Grabski F., Landowski B.: Semi-Markov model of the vehicle maintenance processes in an urban transport system. Scientific Publishers of the Polish Scientific Association of Automotive Engineering, Archives of Automotive Engineering Vol. 7, No 3, 2004.

27. Woropay M., Knopik L., Landowski B.: Modelowanie procesów eksploatacji w systemie transportowym. Biblioteka Problemów Eksploatacji. Wydawnictwo Instytutu Eksploatacji Maszyn, Bydgoszcz - Radom 2001.

28. Woropay M., Landowski B., Neubauer A.: Applying semiMarkov decision processes to model and simulate the bus operation and maintenance processes. Scientific Publishers of the Polish Scientific Association of Automotive Engineering, Archives of Automotive Engineering Vol. 7, No. 1, 2004.

29. Woropay M., Landowski B., Neubauer A.: Simulation of the method to optimise the operation and maintenance process of the buses in an urban transport system. International Scientific Conference "Transport of the 21st Century", section5, Warsaw 2004. 


\section{CONTACT WITH THE AUTHOR}

\section{Bogdan Landowski}

e-mail:bl-sluzbowy@wp.pl

Uniwersytet Technologiczno-Przyrodniczy

im. Jana i Jędrzeja Śniadeckich w Bydgoszczy

Al. prof. S. Kaliskiego 7

85-796 Bydgoszcz

Poland

\section{Michał Pająk}

e-mail:m.pajak@pr.radom.pl

Uniwersytet Technologiczno-Humanistyczny im. Kazimierza Pułaskiego w Radomiu

$$
\begin{gathered}
\text { Malczewskiego } 29 \\
\text { 26-600 Radom } \\
\text { PolAND }
\end{gathered}
$$

\section{Bogdan Żółtowski}

e-mail:bogdan.zoltowski@utp.edu.pl

Uniwersytet Technologiczno-Przyrodniczy

im. Jana i Jędrzeja Śniadeckich w Bydgoszczy

Al. prof. S. Kaliskiego 7

85-796 Bydgoszcz

Poland

\section{Łukasz Muślewski}

e-mail:lukasz.muslewski@utp.edu.pl

Uniwersytet Technologiczno-Przyrodniczy im. Jana i Jędrzeja Śniadeckich w Bydgoszczy

Al. prof. S. Kaliskiego 7

85-796 Bydgoszcz

Poland 